\title{
Faktor-faktor yang Mempengaruhi Pendapatan Usaha Ternak Sapi potong di Kecamatan Sitiung, Kabupaten Dharmasraya
}

\section{Infleuence Factors of Beef Cattle Farm's Income In Sitiung, Dharmasraya District}

\author{
I. Indrayani* dan Andri \\ Fakultas Peternakan Universitas Andalas, Padang, 25163 \\ *E-mail: ida.indrayani@gmail.com \\ (Diterima: 12 Maret 2018; Disetujui: 6 Juni 2018)
}

\begin{abstract}
ABSTRAK
Keberhasilan usaha ternak sapi potong bergantung pada tiga unsur yaitu bibit, pakan, dan manajemen atau pengelolaan. Tujuan Penelitian adalah untuk menghitung pendapatan usaha ternak sapi potong dan menentukan faktor-faktor yang mempengaruhi pendapatan usaha ternak sapi potong di Kecamatan Sitiung Kabupaten Dharmasraya. Jumlah sampel yang digunakan dalam penelitian ini adalah 43 orang peternak sapi potong. Variabel yang diukur adalah pendapataan usaha ternak sapi potong dan faktor-faktor yang mempengaruhi pendapatan usaha ternak sapi potong di Kecamatan Sitiung Kabupaten Dharmasraya. Data dianalisis dengan menggunakan metode analisis pendapatan dan teknik ekonometri dengan menggunakan analisis regresi linear berganda. Hasil penelitian menunjukkan pendapatan peternak dari usaha ternak sapi di Kecamatan Sitiung selama satu tahun adalah sebesar Rp. 8.579.213,- dengan rata-rata kepemilikan ternak 4,3 ekor. Variabel yang berpengaruh nyata terhadap pendapatan usaha ternak sapi potong adalah variabel biaya usaha ternak sapi potong, jumlah ternak yang dipelihara, dan sistem pemeliharaan sapi. Sementara variable pengalaman beternak dan lamanya pendidikan peternak tidak berpengaruh nyata.
\end{abstract}

Kata kunci: pendapatan, regresi linear, sapi potong

\section{ABSTRACT}

The successful of beef cattle farming depend on 3 factors, i.e breed, feed and management. The aim of this research are to calculate the farmer's income and to determine factors influencing farmer's income in Sitiung district, Dharmasraya West Sumatera. In this research 43 sample was used. The variable used on this research are farmers income and factors influencing farmer income in Sitiung district, Dharmasraya region. Data was analyzed by using descriptive Quantitative there was income and econometrict (multiple linear regression). The result showed farmer's income Rp.8.579.213 with mean of cattle ownership 4,3 ahead. The variable significant influencing on farmer's income are cost of beef cattle farming, the number of cattle, and management system. Therefore experience and level of education not significant influence.

Keywords: beef cattle, income, linear regression

\section{PENDAHULUAN}

Strategi pembangunan peternakan mempunyai prospek yang baik di masa depan, karena permintaan akan bahan-bahan yang berasal dari ternak akan terus meningkat seiring dengan peningkatan jumlah penduduk, pendapatan, dan kesadaran masyarakat untuk mengkonsumsi pangan bergizi tinggi sebagai pengaruh dari naiknya tingkat pendidikan rata-rata penduduk (Santosa, 1997).
Usaha ternak merupakan suatu proses mengkombinasikan faktor-faktor produksi berupa lahan, ternak, tenaga kerja dan juga modal untuk menghasilkan produk peternakan. Keberhasilan usaha ternak sapi potong bergantung pada tiga unsur yaitu bibit, pakan, dan manajemen atau pengelolaan. Selain itu pengelolaan maupun manajemen dalam usaha ternak tidak terlepas dari karakteristik sosial ekonomi peternak sehingga nantinya akan mempengaruhi hasil yang akan diperoleh oleh 
peternak.

Usaha ternak sapi potong merupakan usaha yang saat ini banyak dipilih oleh rakyat untuk dibudidayakan. Kemudahan dalam melakukan budidaya serta kemampuan ternak untuk mengkonsumsi limbah pertanian menjadi pilihan utama. Sebagian besar skala kepemilikan sapi potong di tingkat rakyat masih kecil yaitu antara 5 sampai 10 ekor. Hal ini dikarenakan usaha ternak yang dijalankan oleh rakyat umumnya hanya dijadikan sampingan yang sewaktu-waktu dapat digunakan jika peternak memerlukan uang dalam jumlah tertentu (Sugeng, 1992).

Pada usaha peternakan rakyat biasanya peternak berfungsi sebagai pembuat keputusan yang berusaha mengambil keputusan yang efektif dan efisien dalam menjalankan dan mengelola usaha ternaknya. Karakteristik sosial ekonomi peternak (Jumlah ternak, umur, tingkat pendidikan, lamanya beternak, jumlah tanggungan keluarga, jumlah tenaga kerja, luas kandang, jumlah investasi, total penerimaan produksi dan total biaya produksi) dapat mempengaruhi peternak dalam mengambil keputusan yang dapat memberikan keuntungan bagi usaha ternaknya. Sehingga dari karakteristik sosial ekonomi tersebut nantinya akan mempengaruhi pendapatan yang diperoleh per peternak sehingga perlu diidentifikasi faktor-faktor yang mempengaruhi pendapatan peternak sapi potong (Siregar, 2013).

Kabupaten Dharmasraya merupakan salah satu Kabupaten yang berpotensi untuk pengembangan sapi potong. Jumlah sapi potong di Kabupaten Dharmasraya pada tahun 2015 adalah 40.788 ekor (BPS Kabupaten Dharmasraya, 2015). Kecamatan Sitiung adalah daerah dengan populasi ternak sapi terbanyak di Kabupaten Dharmasraya yaitu dengan populasi tahun 2015 berjumlah 9.468 ekor dibanding Kecamatan lain yang ada di Kabupaten Dhamasraya (BPS Kabupaten Dharmasraya, 2015) dan jumlah rumahtangga pemelihara ternak di Kecamatan Sitiung pada tahun 2015 berjumlah 1.840 (UPTD PUSKESWAN Kecamatan Pulau Punjung,
2015).

Sistem pemeliharaan sapi potong di Kecamatan Sitiung terdiri dari sistem intensif dan semiintensif. Usaha ini merupakan usaha turun-temurun dan merupakan peternakan rakyat yang umunya peternak memberikan pakan berupa hijauan berupa rumput lapangan dan pakan tambahan berupa konsentrat, namun konsentrat diberikan tidak kontinu, peternak umumnya tidak mengerti nilai padang penggembalaan dan peternak biasanya tidak mengusahakan lahan yang cukup untuk memungkinkan peternak menanam tanaman khusus sebagai pakan ternak, sapi-sapi dibiarkan merumput mencari makan pada wilayah penggembalaan. Padahal sistem pemeliharaan yang baik akan memberikan hasil produksi yang jauh lebih baik pula.

Usaha peternakan sapi potong didominasi oleh peternakan rakyat yang berskala kecil. Peternakan bukanlah suatu hal yang jarang dilaksanakan. Hanya saja skala pengelolaannya masih merupakan usaha sampingan yang tidak diimbangi dengan permodalan dan pengelolaan yang memadai. Hampir semua rumah tangga (terutama di pedesaan) yang mengusahakan ternak sebagai kegiatan sehari-hari.

Pengembangan sapi potong sebagai salah satu ternak potong masih banyak mengalami hambatan karena pemeliharaanya yang masih bersifat tradisional, sangat tidak menguntungkan karena tidak berproduksi secara maksimal. Hal ini diduga disebabkan oleh berbagai faktor sosial ekonomi peternak terutama terkait penerimaan yang diterima dan biaya yang dikeluarkan masing-masing peternak. Selain itu berbagai faktor lain seperti skala usaha, status kepemilikan ternak, pendidikan peternak dan pengalaman akan mempengaruhi besar-kecilnya penerimaan dan pendapatan yang akan diperoleh oleh masing-masing peternak. Berbagai persoalan di atas tentunya dapat menjadi hambatan bagi peternak dalam laju peningkatan produksi sapi potong.

Berdasarkan uraian di atas, maka 
penelitian ini bertujuan untuk menentukan faktor-faktor sosial dan ekonomi yag mempengaruhi besar kecilnya pendapatan yang diperoleh peternak sapi potong.

Tujuan dari penelitian ini adalah: 1) Untuk menganalisis pendapatan usaha ternak sapi potong di Kecamatan Sitiung Kabupaten Dharmasraya, dan 2) Untuk menentukan faktor-faktor yang mempengaruhi pendapatan usaha ternak sapi potong di Kecamatan Sitiung Kabupaten Dharmasraya.

\section{METODE}

Penelitian ini dilaksanakan di Kecamatan Sitiung Kabupaten Dharmasraya. Pemilihan tempat ini dilaksanakan dengan pertimbangan bahwa Kecamatan Sitiung merupakan salahsatukecamatanyang memiliki jumlah populasi sapi potong terbanyak yang ada di Kabupaten Dharmasraya.

Populasi dalam penelitian ini adalah semua peternak yang ada di Kecamatan Sitiung Kabupaten Dharmasraya yang memiliki sapi potong. Jumlah rumahtangga pemelihara ternak di Kecamatan Sitiung pada tahun 2015 berjumlah 1.840 . Untuk keperluan penelitian jumlah sampel yang akan diambil ditentukan berdasarkan rumus sebagai berikut:

$$
n=\frac{N}{1+N\left(e^{2}\right)}
$$

Keterangan :

$\mathrm{n}$ : jumlah sampel

$\mathrm{N}$ : jumlah populasi

e : kesalahan yang ditolerir

$$
n=\frac{1.840}{1+1840\left(0.15^{2}\right)}=43
$$

Variabel yang diukur dalam penelitian ini adalah:

a. Pendapataan usaha ternak sapi potong di Kecamatan Sitiung:

1) Penerimaan Usaha ternak sapi potong dalam satu tahun
2) Biaya produksi usaha ternak sapi potong dalam satu tahun

b. Faktor-faktor yang mempengaruhi pendapatan usaha ternak sapi potong di Kecamatan Sitiung yaitu :

1) Jumlah biaya yang dikeluarkan dalam usaha ternak sapi potong (Rupiah)

2) Skala atau jumlah ternak sapi potong yang dipelihara (ST)

3) Status kepemilikan sapi potong (milik sendiri atau seduaan)

4) Pengalaman beternak (tahun)

5) Pendidikan peternak (tahun)

Data yang dibutuhkan dalam penelitian ini berupa data primer dan data sekunder. Data primer diperoleh melalui observasi langsung dilapangan berupa wawancara dengan peternak sapi potong di lokasi penelitian yang berpedoman pada daftar pertanyaan yang telah disusun sesuai dengantujuan penelitian. Sedangkan data sekunder diperoleh melalui studi kepustakaandan dari berbagai instansi.

Data yang diperoleh dari hasil wawancara responden dilapangan diolah dan ditabulasi. Kemudian data dianalisis dengan menggunakan metode analisis pendapatan dan diolah dengan model pendekatan ekonometri dan dijelaskan secara metode deskriptif. Adapun untuk menghitung pendapatan dari kegiatan beternak sapi, dapat dihitung dengan rumus (Soekartawi, 1995).

$$
\mathrm{Pd}=\mathrm{TR}-\mathrm{TC}
$$

Keterangan:

$\mathrm{Pd}=$ total pendapatan atau keuntungan yang diperoleh peternak sapi potong (rupiah/ tahun)

$\mathrm{TR}=$ total revenue atau penerimaan yang diperoleh peternak sapi potong (rupiah/ tahun)

$\mathrm{TC}=$ total biaya yang dikeluarkan peternak sapi potong (rupiah/tahun)

Untuk melihat faktor-faktor yang mempengaruhi pendapatan dapat dilihat 
dengan menggunakan Model Pendekatan Teknik Ekonometri dengan menggunakan analisis regresi linear berganda alat bantu Software SPSS. Model digambarkan sebagai berikut:

$$
\begin{gathered}
\hat{\mathrm{Y}}=\mathrm{a}+\mathrm{b} 1 \mathrm{X} 1+\mathrm{b} 2 \mathrm{X} 2+\mathrm{b} 3 \mathrm{X} 3+\mathrm{b} 4 \mathrm{X} 4+ \\
\mathrm{b} 5 \mathrm{X} 5+\mu
\end{gathered}
$$

Keterangan:

$\hat{\mathrm{Y}}$ (Y : topi) : pendapatan peternak yang dipengaruhi berbagai faktor dalam memelihara ternak sapi potong (rupiah/ tahun)

a : koefisien Intercept (konstanta)

b1 b2 b3 b4 b5 : koefisien regresi

$\mathrm{X} 1$ : jumlah biaya yang dikeluarkan dalam usaha ternak sapi potong (rupiah/tahun)

$\mathrm{X} 2$ : skala atau jumlah ternak sapi yang dipelihara (satuan ternak)

X3 : status kepemilikan sapi potong (milik sendiri atau seduaan)

$\mathrm{X} 4$ : pengalaman beternak (tahun)
X5 : lamanya pendidikan (tahun)

$\mu$ : variabel lain yang tidak diteliti

Jika variabel tersebut berpengaruh secara serempak. Maka menurut (Sudjana, 2002) digunakan uji F yakni:

$$
r 2 / k \quad F=(1-r 2) /(n-k-1)
$$

Keterangan:

$$
\begin{aligned}
& \mathrm{R} 2 \quad=\text { Koefisien determinasi } \\
& \mathrm{n} \quad=\text { Jumlah responden } \\
& \mathrm{k} \quad=\text { Derajat bebas pembilang } \\
& \mathrm{n}-\mathrm{k}-1=\text { Derajat bebas penyebut } \\
& \quad \text { Kriteria uji: F-hit } \leq \text { F-tabel }(\mathrm{H} 0 \\
& \text { diterima (H1 ditolak)) ; F-hit }>\text { F-tabel }(\mathrm{H} 0 \\
& \text { ditolak (H1 diterima)). }
\end{aligned}
$$

\section{HASIL DAN PEMBAHASAN}

\section{Karakteristik Peternak Sapi Potong di Kecamatan Sitiung}

Peternak responden dalam penelitian

Tabel 1. Karakteristik Peternak Sapi Potong di Kecamatan Sitiung

\begin{tabular}{lcc}
\hline Karakteristik & Jumlah responden & Persentase \\
\hline Umur (tahun) & 4 & 9,5 \\
$24-37$ & 17 & 40,5 \\
$38-51$ & 21 & 50,0 \\
$52-65$ & & \\
\hline Pendidikan & 17 & 40,5 \\
Tamat SD & 16 & 38,1 \\
Tamat SMP & 19 & 21,4 \\
Tamat SMA & & \\
Pengalaman beternak & 13 & 31,0 \\
$1-9$ tahun & 11 & 26,2 \\
$10-19$ tahun & 18 & 42,9 \\
$20-29$ tahun & & \\
Jumlah ternak (ekor) & 33 & 78,6 \\
$2-4$ & 8 & 19,0 \\
$5-7$ & 1 & 2,4 \\
$8-10$ & & \\
\hline
\end{tabular}


ini adalah peternak sapi yang mengusahakan usaha pembibitan sapi potong di Kecamatan Sitiung. Pemeliharaan sapi potong yang diusahakan oleh peternak bersifat tabungan/ dapat dijual kapan pun. Sebagian besar mata pencaharian masyarakat Sitiung adalah bertani dan berkebun. Beberapa karakteristik responden yang dianggap penting meliputi: umur, pendidikan, pengalaman beternak, jumlah ternak, dan sistem pemeliharaan (Tabel 1).

\section{Umur}

Umur merupakan usia responden pada saat dilakukan penelitian yang dihitung dalam satuan tahun. Umur merupakan salah satu indikator kemampuan fisik seseorang. Seseorang yang memiilki umur lebih muda cenderung akan memiliki kemampuan fisik yang lebih kuat dari pada mereka yang memiliki umur yang lebih tua. Umur peternak dapat mempengaruhi produktifitas seseorang karena erat kaitannya dengan kemampuan kerja serta pola pikir dalam menentukan bentuk serta pola manajemen yang diterapkan dalam usaha. Klasifikasi responden berdasarkan tingkat umur yang ada di Kecamatan Sitiung kabuaten Dharmasraya mayoritas berumur diatas 52 tahun. Soekartawi (2002), menyatakan bahwa para petani yang berusia lanjut biasanya fanatik terhadap tradisi dan sulit untuk diberikan pengertian-pengertian yang dapat mengubah cara berpikir dan cara pandang guna meningkatkan kemajuan dari segi usaha taninya, cara kerja dan cara hidupnya. Petani ini bersikap apatis terhadap adanya teknologi baru.

\section{Pendidikan}

Tingkat pendidikan responden terdiri dari mayoritas atau $40,5 \%$ Sekolah Dasar (SD), SMP sebanyak 38,1\%, dan SMA sebanyak $21,4 \%$. Dari tingkat pendidikan terlihat bahwa pendidikan peternak masih rendah. Tingkat pendidikan memiliki pengaruh terhadap usahaternak baik secara teknis, pengelolaan maupun terhadap manajemen usahaternak dalam penyerapan teknologi baru, dengan tingkat pendidikan yang tinggi diharapkan para peternak mampu menjalankan kegiatan usaha ternaknya dengan lebih baik, karena didukung oleh pengetahuan dan wawasan yang semakin luas.

\section{Pengalaman beternak}

Pengalaman beternak pada responden dibagi menjadi tiga, dimana 1-9 sebanyak $31 \%$, 10-19 sebanyak $26,2 \%$ dan 20-29 sebanyak $42,9 \%$. Dari hasil tersebut menunjukkan bahwa peternak sapi potong di Sitiung sudah mempunyai pengalaman yang cukup lama dimana mayoritas sudah berpengalaman lebih dari 20 tahun. Pengalaman dalam usaha ternak dapat mempengaruhi kemampuan dalam mengelola usaha ternak, dengan pengalaman yang cukup lama peternak memiliki pemahaman yang lebih baik terhadap usaha ternak yang dijalankannya.

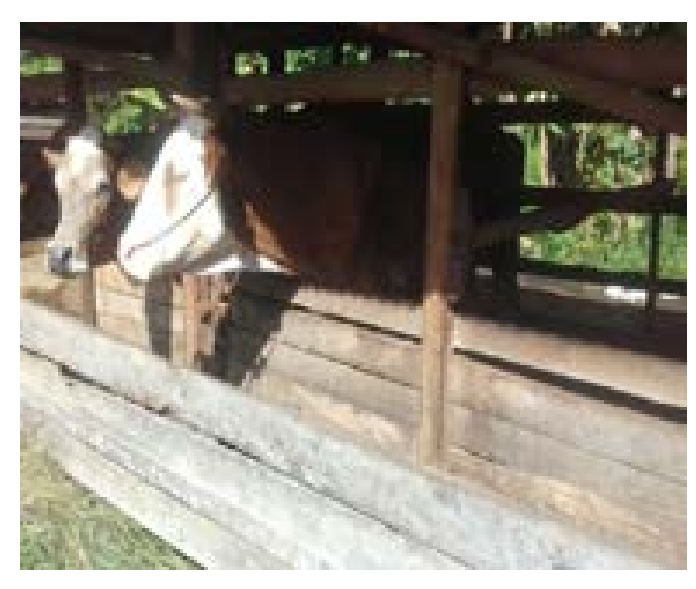

Gambar 1. Sapi Simental yang dipelihara peternak di Kecamatan Sitiung 


\section{Jumlah Ternak Yang dipelihara}

Jenis ternak sapi yang dipelihara peternak yaitu Sapi Simmental (Gambar 1). Jumlah ternak sapi yang dipelihara rata-rata 4,3 ekor dengan rentang kepemilikan 78,6\% memiliki ternak antara 2-4 ekor, $19 \%$ peternak memiliki ternak 5-7 ekor dan hanya 2,4\% dengan kepemilikan ternak 8-10 ekor. Hasil penelitian menunjukkan bahwa sebagian besar peternak memiliki skala kepemilikan ternak sapi yang masih kecil, hal ini karena beternak masih sebagai usaha sampingan. Umumnya pekerjaan utama peternak sapi di kecamatan sitiung adalah adalah bertani dan berkebun.

\section{Sistem Pemeliharaan}

Sistem pemeliharaan ternak sapi menerapkan pola intensif dan semiintensif, dimana $71,4 \%$ menerapkan pola intensif dan $28,6 \%$ dengan pola semiintensif. Sisitem pemeliharaan semi intensif pada siang hari ternak dilepaskan di padang pengembalaan dan pada malam hari dikandangkan, sedangkan untuk yang intesif sapi dikandangkan secara terus-menerus. Karena sapi dikandangkan, maka peternak harus menyediakan pakan ternak berupa hijauan dan konsentrat. Hijauan yang diberikan umumnya berupa rumput lapangan, sedangkan konsentrat hanya sebagian kecil peternak yang memberikan yaitu berupa dedak dan ampas tahu.

\section{Analisis Pendapatan Usaha Ternak Sapi Potong di Kecamatan Sitiung}

Penerimaan. Penerimaan peternak sapi di Kecamatan Sitiung berasal dari banyaknya penjualan ternak sapi dalam satu tahun dikalikan harga ternak, dimana dari hasil penelitian didapatkan penerimaan tunai peternak dari penjualan ternak sapi rata-rata sebesar Rp. 9.376.190,- atau 41,4 \% dari total penerimaan, dan pertambahan nilai ternak setelah dipelihara selama satu periode ratarata sebesar Rp. 13.284.524,- atau 58,6\% dari total penerimaan (Tabel 2).

Tabel 2. Laporan Laba Rugi Usaha Peternakan Sapi Potong di Kecamatan Sitiung (1 Tahun analisis)

\begin{tabular}{lrr}
\hline Uraian & Jumlah (Rp) & Persen (\%) \\
\hline Penerimaan & & \\
Penjualan Sapi & 9.376 .190 & 41,4 \\
Pertambahan Nilai Sapi & 13.284 .524 & 58,6 \\
\hline Total Penerimaan & 22.660 .714 & \\
\hline Biaya Variabel: & & 49,4 \\
Biaya Hijauan & 6.952 .381 & 2,3 \\
Biaya Dedak & 321.905 & 2,4 \\
Biaya Ampas Tahu & 334.286 & 38,6 \\
Biaya Tenaga Kerja & 5.431 .548 & 0,2 \\
Biaya ib & 26.190 & 92,8 \\
\hline Jumlah Biaya Variabel & 13.066 .310 & 5,5 \\
\hline Biaya Tetap: & & 1,6 \\
Penyusutan kandang & 777.477 & 7,2 \\
Penyusutan peralatan & 231.286 & 100,0 \\
\hline Jumlah Biaya Tetap & 1.008 .763 & \\
\hline Total Biaya Produksi & 14.075 .073 & 8.579 .213 \\
\hline Pendapatan & &
\end{tabular}


Tabel 3. Hasil Output Analisis Regresi Linier Berganda

\begin{tabular}{lrrrr}
\hline Variabel & Koefisien Regresi & Std. Error & t- hitung & Signifikan \\
\hline Konstanta & $-0,000007463$ & 0,000006841 & $-1,091$ & 0,283 \\
X1 & $-1,294$ & 0,528 & $-2,451$ & 0,019 \\
X2 & 0,000006243 & 0,000001268 & 4,922 & 0,000 \\
X3 & 0,000007176 & 0,000002974 & 2,413 & 0,021 \\
X4 & 140506,317 & 194360,787 & 0,723 & 0,474 \\
X5 & $-22921,365$ & 525101,456 & $-0,044$ & 0,965 \\
\hline R square & 0,546 & & \\
F hitung & 8,668 & & & \\
\hline
\end{tabular}

Produksi. Biaya total produksi peternak sapi di Kecamatan Sitiung terdiri dari biaya tetap dan biaya Variabel. Biaya tetap (fixed cost) adalah biaya yang tidak berubah walaupun volume produksinya berubah-ubah. Biaya variabel (variabel cost) adalah biaya yang jumlahnya berubah tergantung pada volume produksi dan habis digunakan untuk satu kali proses produksi. Rataan Total Biaya adalah sebesar Rp.14.075.073,-. Komponen biaya terbesar yang dikeluarkan peternak adalah biaya hijauan yaitu Rp.6.952.381,atau $(49,4 \%)$. Biaya hijauan didekati dari jumlah jam kerja peternak mencari hijauan dikali dengan

Pendapatan. Dari alat analisis yang digunakan maka diperoleh pendapatan peternak sapi di Kecamatan Sitiung selama satu tahun rata-rata sebesar Rp. 8.579.213,dengan rata-rata kepemilikan ternak 4,3 ekor. Dengan demikian pendapatan peternak ratarata adalah Rp.714.934,- /bulan. Berdasarkan penerimaan dan biaya yang dikeluarkan maka diperoleh $\mathrm{R} / \mathrm{C}$ rasio sebesar 1,61, hal ini berarti bahwa untuk pengorbanan sebesar 1 maka akan mendapatkan penerimaan sebesar 1,61. Dari hasi tersebut berarti usaha pembibitan sapi potong yang dijalankan peternak di Kecamatan Sitiung menguntungkan karena R/ $\mathrm{C}>1$, ini sesuai dengan pendapat Soekartawi (1995) yang menyatakan jika nilai $\mathrm{R} / \mathrm{C}>1$ berarti usaha tersebut menguntungkan dan layak untuk diteruskan. Jika dibandingkan dengan penelitian Dinata (2018) tentang faktor yang mempengaruhi pendapatan usaha ternak sapi potong di Kecamatan Kuranji Kota Padang dengan nilai $\mathrm{R} / \mathrm{C}$ rasio 1,21 , maka nilai $\mathrm{R} / \mathrm{C}$ rasio usaha ternak sapi potong di Kecamatan Sitiung lebih menguntungkan.

\section{Faktor-Faktor Yang mempengaruhi pendapatan Usaha Ternak Sapi potong di Kecamatan Sitiung}

Untuk menguji faktor-faktor yang mempengaruhi usaha ternak sapi potong di Kecamatan Sitiung digunakan analisis regresi linier berganda, dimana yang menjadi variabel bebas (independent) adalah total biaya yang dikeluarkan (X1), Jumlah ternak yang dipelihara (X2), system pemeliharaan sapi (X3), pengalaman beternak (X4), lamanya pendidikan (X5), sedangkan yang menjadi variabel terikat/tidak bebas (dependent) adalah pendapatan (Y). Adapun hasil pengujian faktor-faktor yang mempengaruhi pendapatan usaha ternak sapi potong di Kecamatan Sitiung dapat di lihat pada Tabel 3.

Berdasarkan Hasil Regresi diatas dapat diketahui Secara serempak nilai F-hitung $(8,668)$ dan signifikan pada taraf $1 \%$ yang artinya bahwa secara serempak kelima variabel tersebut yaitu biaya yang dikeluarkan (X1), Jumlah ternak yang dipelihara (X2), system pemeliharaan sapi (X3), pengalaman beternak (X4), dan lamanya pendidikan (X5) berpengaruh secara nyata terhadap pendapatan usaha ternak sapi potong di Kecamatan Sitiung Kabupaten Dharmasraya.

Secara partial nilai t-hitung variabel yang berpengaruh nyata terhadap pendapatan 
usaha ternak sapi potong adalah variabel biaya usaha ternak sapi potong, jumlah ternak yang dipelihara, dan sistem pemeliharaan sapi. Sementara variabel pengalaman beternak dan lamanya pendidikan peternak tidak berpengaruh nyata. Biaya yang dikeluarkan untuk usaha sapi potong. Dari hasil uji-t diatas diperoleh nilai-p $(0,019)<$ alpha $5 \%$ maka tolak $\mathrm{H} 0$ artinya biaya yang dikeluarkan untuk usaha sapi potong berpengaruh nyata terhadap pendapatan dengan koefisien regresi bertanda negative. Hal ini menunjukkan peningkatan jumlah biaya yang dikeluarkan akan menyebabkan penurunan jumlah pendapatan peternak. Jumlah ternak yang dipelihara. Hasil uji-t diperoleh nilai-p $(0,00)$ $<$ dari alpha $1 \%$ maka tolak $\mathrm{H} 0$, artinya jumlah ternak yang dipelihara berpengaruh nyata terhadap pendapatan usaha ternak sapi potong. Hal ini menunjukkan bahwa semakin banyak jumlah ternak yang dipelihara maka akan semakin besar pula pendapatan yang akan diperoleh peternak sapi potong. Menurut Soekartawi (1995), bahwa pendapatan usaha ternak sapi sangat dipengaruhi oleh banyaknya ternak yang dijual oleh peternak itu sendiri sehingga semakin banyak jumlah ternak sapi maka semakin tinggi pendapatan bersih yang diperoleh.

Sistem pemeliharaan sapi. Hasil uji-t diperoleh nilai $-\mathrm{p}(0,021)<$ dari alpha $5 \%$ maka tolak H0, artinya sistem pemeliharaan sapi berpengaruh nyata terhadap pendapatan. Nilai koefisien regresi bertanda positif artinya dengan pemeliharaan secara intensif akan meningkatkan pendapatan usaha ternak sapi potong. Hal ini karena dengan pemeliharaan intesif pemberian pakan akan lebih terkontrol, pengaturan perkembangbiakan, pengawasan terhadap kesehatan dan pencegahan penyakit sehingga berpengaruh terhadap produktifitas sapi.

Pengalaman beternak. Dari hasil uji-t diatas diperoleh nilai-p $(0,474)>$ alpha $10 \%$ maka terima $\mathrm{H} 0$ artinya pengalaman beternak tidak berpengaruh nyata terhadap pendapatan. Umumnya pengalaman beternak diperoleh dari orang tuanya secara turun-temurun.
Pengalaman beternak yang cukup lama memberikan indikasi bahwa pengetahuan dan keterampilan peternak terhadap manajemen pemeliharaan ternak mempunyai kemampuan yang lebih baik. Namun di lapangan tidak diperoleh pengaruh seperti yang diharapkan. Hal ini dapat disebabkan banyak peternak yang memiliki pengalaman yang memadai namun masih mengelola usaha tersebut dengan kebiasaan-kebiasaan lama yang sama dengan sewaktu mereka mengawali usahanya sampai sekarang. Menurut Abidin dan Simanjuntak (1997), faktor penghambat berkembangnya peternakan pada suatu daerah tersebut dapat berasal dari faktor-faktor topografi, iklim, keadaaan sosial, tersedianya bahan-bahan makanan rerumputan atau penguat.

Pendidikan peternak. Dari hasil uji-t diatas diperoleh nilai-p $(0,965)>$ alpha $10 \%$ maka tolak H0 artinya pendidikan tidak berpengaruh nyata terhadap pendapatan. Tingkat pendidikan peternak cenderung mempengaruhi cara berpikir dan tingkat penerimaan mereka terhadap inovasi dan teknologi baru. Peternak yang tingkat pendidikannya lebih tinggi seharusnya dapat meningkatkan pendapatan peternak yang lebih besar. Namun tidak demikian halnya pada peternak sapi potong di Kecamatan Sitiung.

Tidak jauh berbeda dengan Hasil penelitian Maryam et al. (2016) yang menunjukkan bahwa skala usaha, biaya produksi, dan modal usaha merupakan faktor penentu yang mempunyai hubungan positif dan signifikan terhadap pendapatan usaha peternakan sapi potong di Desa Otting Kecamatan Tellu Siattinge Kabupaten Bone Sulawesi Selatan. Sedangkan umur peternak, tingkat pendidikan, pengalaman berternak, dan jumlah tenaga kerja mempunyai hubungan negatif dan tidak signifikan terhadap pendapatan usaha peternakan sapi potong.

Penelitian Bahta dan Baker (2015) menunjukkan bahwa faktor yang berpengaruh signifikan terhadap keuntungan peternak pada usaha sapi potong skala kecil (dibawah 10 ekor) di Botswana adalah harga pakan, 
biaya obat dan kesehatan ternak, biaya tenaga kerja, nilai modal tetap dan jumlah jam kerja keluarga. Sedangkan pada skala diatas 20 ekor faktor yang berpengaruh signifikan adalah biaya obat dan kesehatan ternak, biaya tenaga kerja, jumlah jam kerja keluarga dan luas lahan panen.

\section{KESIMPULAN}

1. Pendapatan peternak sapi di Kecamatan Sitiung selama satu tahun dengan rataan sebesar Rp. 8.579.213,- dengan rata-rata kepemilikan ternak 4,3 ekor. Dengan demikian pendapatan peternak rata-rata adalah Rp.714.934,- /bulan.

2. Berdasarkan Hasil Regresi variabel yang berpengaruh nyata terhadap pendapatan usaha ternak sapi potong adalah variabel biaya usaha ternak sapi potong, jumlah ternak yang dipelihara, dan system pemeliharaan sapi. Sementara variable pengalaman beternak dan lamanya pendidikan peternak tidak berpengaruh nyata.

\section{DAFTAR PUSTAKA}

Abidin, A dan Simanjuntak, D. 1997. Ternak Sapi Potong. Direktorat Jenderal Peternakan, Jakarta.

Badan Pusat Statistik KabupatenDharmasraya. 2015. Dharmasraya Dalam Angka 2015. BPS Kabupaten Dharmasraya.

Bahta, S dan Baker, D. 2015. Determinants of Profit Efficiency among Smallholder Beef Producers in Botswana. International Food and Agribusiness Management Review Volume 18 Issue 3: 107-130.

Dinata, I. 2018. Analisis Pendapatan dan Faktor-Faktor yang Mempengaruhi Pendapatan Usaha Pembibitan Sapi Potong di Kecamatan Kuranji Kota Padang. Skripsi. Fakultas Peternakan Universitas Andalas, Padang.
Maryam, M.B.P dan Astati. 2016. Analisis Faktor-Faktor Yang Mempengaruhi Penentu Pendapatan Usaha Peternakan Sapi Potong (Studi Kasus Desa Otting Kab. Bone). JurnalIlmu dan Industri Peternakan. Vol 3, No.1.

Santosa, U. 1997. Prospek Agribisnis Penggemukan Pedet. Penebar Swadaya, Jakarta.

Siregar, N.W.P. 2013. Faktor - Faktor Yang Mempengaruhi Usaha Ternak Sapi Potong Di Desa Mangkai Lama Kecamatan Lima Puluh Kabupaten Batu Bara Provinsi Sumatera Utara. skripsi. Bogor. Fakultas Ekonomi dan Manajemen. Institut Pertanian Bogor.

Soekartawi. 1995. Analisis Usaha Tani. UIPress, Jakarta.

Soekartawi. 2002. Prinsip Dasar Ekonomi Pertanian Teori dan Aplikasi. Jakarta: PT. Raja Grafindo.

Sudjana. 2002. Metode Statistika. Edisi keenam. Tarsito, Bandung.

Sugeng, Y.B. 2006. Sapi Potong. Penebar Swadaya, Jakarta.

UPTD Pusat Kesehatan Hewan Kecamatan Pulau Punjung. 2015. Jumlah Rumah Tangga Pemelihara Ternak. UPTD Pusat Kesehatan Hewan Kecamatan Pulau Pujung. 